\title{
Treatment of Wastewater for Agricultural Applications in Regions of Water Scarcity
}

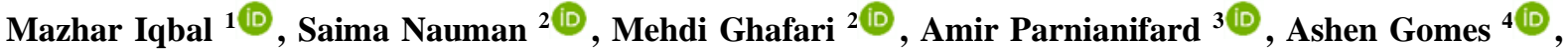 \\ Chandima Gomes 5 ,*iD

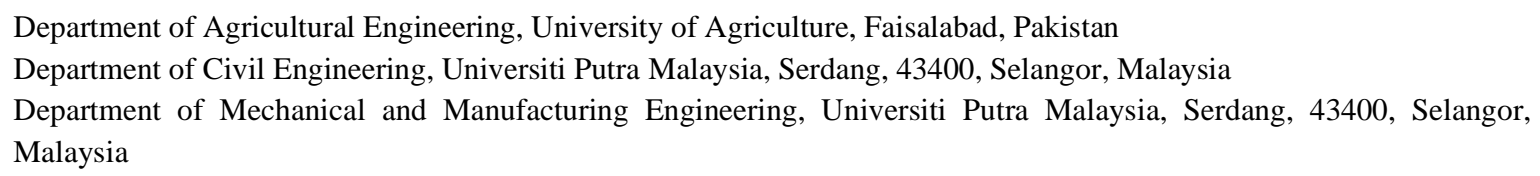

Received: 27.07.2021; Revised: 25.09.2021; Accepted: 1.10.2021; Published: 18.11.2021

\begin{abstract}
This paper analyses the latest techniques for treating wastewater to make it suitable for agricultural applications in regions where irrigation water is scarce. Micro-filtration (MF) techniques yield a significant reduction in Chemical Oxygen Demand (COD), Biological Oxygen Demand (BOD), Total Suspended Solids (TSS), and Total Bacterial Count (TBC) of wastewater, which makes it suitable to be used for irrigational purposes. Microbial Fuel Cell (MFC) technology is a viable solution for treating wastewater discharged from many industrial sectors, such as the food processing industry, for reclaiming water for agro-applications. Such industrial water may seal soil pores if directed untreated to agricultural fields. Concerning the treatment of microbial contamination of wastewater, the removal rate of pressurized membrane bio-booster (MBR) is significantly large for coliform and metals such as lead, copper, chromium, and arsenic. Both electrocoagulation and chemical coagulation are applied in the removal of oxidable chemicals from wastewater. However, the electrocoagulation process shows a higher efficiency in terms of removing COD. Contamination of agricultural fields with heavy metals is considered an adverse impact on the human and animal safety of discharging wastewater into agrofields. Thus, removing such contaminants should be given the utmost priority in wastewater treatment, especially from industrial discharge, before they are directed to agricultural usage. Factors that govern the sustainability of a given method in a water-scarce region are also discussed.
\end{abstract}

Keywords: wastewater conversion; membrane filtration; chemical coagulation; electrocoagulation; waste stabilization ponds; batch reactor; Fenton process.

(C) 2021 by the authors. This article is an open-access article distributed under the terms and conditions of the Creative Commons Attribution (CC BY) license (https://creativecommons.org/licenses/by/4.0/).

\section{Introduction}

The available fresh water on earth can easily fulfill human demand. However, only about $1 \%$ of the total freshwater volume is accessible for human consumption. Even this accessible water is enough to fulfill the needs of a population ten times larger than that we have today if it could be distributed evenly [1].

Agricultural usage of fresh water is more than $70 \%$ of the total freshwater consumption in the world [2]. Contamination of surface and groundwater by industrial effluents is the cause of water shortage in industrialized countries, whereas, in developing countries, sewage from urban and built-in areas is a major source of water deterioration [3,4]. In regions where 
freshwater resources are limited, there is a need to find alternative sources to meet agro-water requirements. Industrial wastewater and sewage can be potential sources $[5,6]$ for this purpose. The use of recycled water reduces the political and social pressure on existing water sources and minimizes the effluent disposal load to the soil surface [7]. Heavy metals and high inorganic nutrient contents present in these sources can harm the soil and, in turn, crops. As such, the safety of reusing wastewater is still questionable in some parts of the world. Therefore, it is necessary to treat the wastewater before using it in the agricultural field to achieve the recommended quality parameters. This is the only way to minimize the potential threat of the long-term application of wastewater to agricultural fields. Important parameters that affect wastewater quality include $\mathrm{pH}$, salinity, heavy metals, total dissolved solids (TDS), and sodium adsorption ratio (SAR) [8,9]. These parameters control the accumulation of salts and sodicity in the soil and their effects on soil fertility [10]. Reclamation technologies such as membrane filtration, stabilization ponds, and membrane bioreactors can be used for this purpose. Conventional treatment [11.12] and monitoring methods equipped with modern remote sensing techniques $[13,14]$ can also be applied to make wastewater fit for irrigation.

The use of membrane technology in the wastewater treatment industry increases due to its success in the desalination process [15]. This includes reactor treatment of wastewater for irrigation, a combination of membrane, biological or chemical coagulation. There are three important methods in this regard are the Fenton process, batch reactor, and solar photo-Fenton. The use of each type is dependent on the quality of influent that is to be treated and the expected level of treatment.

Despite the general practice of releasing wastewater for irrigational purposes after primary treatment, recent studies on the toxicity and heavy metal contents in the wastewater after primary treatment demand that in the cases of some industrial effluents, a secondary treatment process is essentially required before the water is released for irrigational purposes $[16,17]$.

The significance of reclaimed water from wastewater sources increases as the amount of available freshwater for agriculture diminishes with time or in cases of the landscape where there is inherent water scarcity. Thus, the development of technology for producing water for reusing directly links to the water scarcity of a given region. At geographical locations with seasonal or occasional heavy precipitation, the most popular wastewater water source could be stormwater and surface runoff water. As the water scarcity aggravates, the wastewater sources may be expanded to factory effluents, mining and other similar industry effluents, municipality discharges, and finally, even sewages and septic discharges. Thus, the technology used for water treatments should be changed or modified at different levels of water scarcity. Hence, a comprehensive review covering all types of water treatment methods is in demand at present; thus, based on the level of water need, one could adopt the best method suited for a given case.

Angelakis et al. [18] and Asano et al. [19] have covered this subject in general in detail. A few other studies have discussed the recent development in wastewater treatment methods in developing countries [9,20-22]; however, they have not paid enough attention to wastewater recycling for agricultural purposes, especially with attention to various levels of water scarcity. This paper has been developed in fulfilling the need for information compilation and analysis in such cases.

\section{Methodology}


The method of the literature survey that has been adopted in this study is similar to that is followed by Ricart and Rico [23]. A comprehensive literature survey was conducted in the field of water treatment with special attention to the application of used water for irrigational activities. Altogether, the team of authors collected 592 cited papers from Web of Science, SCOPUS, Directory of Open Access Journals (DOAJ), and IEEE Explorer databases. In papers without open access facility, the complete publications were downloaded by the access rights provided by three universities; Universiti Putra Malaysia, Royal Institute of Technology-KTH, Sweden, and the University of the Witwatersrand, South Africa; to their staff and registered postgraduate students. In addition to the papers extracted from the above databases, another 57 non-cited papers, of which the contents were highly relevant to the analysis, were mined from the Google Scholar database.

In the keyword search, the individual words used for mining research papers for this study are wastewater, coagulation, electrocoagulation, Fenton, and microfiltration. However, most of the publications were mined by searching relevant multi-word terms with AND operator in between words: water scarcity; water treatment; water reuse; wastewater irrigation, membrane filtration; chemical coagulation, waste stabilization pond; batch reactor; and heavy metals.

Information has first been accumulated in chronological order by going through the title, abstract, and conclusions. The papers collected were filtered off with a subjective analysis to select the most relevant work for this study. The collected papers were divided among the author-team for analysis, during which the most pertinent papers for the study were filtered off. Each member was assigned with a certain number of publications, and there was no crossexamination done on the process after each member selected the papers to be analyzed. Finally, there were 131 publications selected and cited in this study.

The chronologically arranged information was then reorganized as per the flow of analysis. Note that information from web pages and unpublished articles have not been incorporated as references in the text; however, wherever it is relevant to the discussion, the complete details of documents by statutory bodies, such as UNO and WHO, have been provided.

\section{Information Analysis}

Many countries have considered the importance of converting wastewater for irrigation usage in recent times. Several studies have been carried out to investigate the reclamation of wastewater for irrigation purposes [24-26]. The process has its advantages and drawbacks, especially concerning the long-term effects on the soil condition [27]. The treated water should be suitable for various irrigation levels and regimes to have an optimized yield $[4,28,29]$. The present study highlights the treatment technologies applied to make the wastewater fit for irrigation purposes. Various treatment methods that can be effectively used for wastewater treatment are available, and all of them focus on the quality of water required after undergoing the treatment process. These treatment processes tend to reduce salinity, pathogenic content, heavy metals, and harmful compounds that could harm the agricultural fields and the living beings that come in direct or indirect contact with untreated water [30,31]. The methods discussed below include membrane filtration, chemical and electrochemical coagulation, batch reactor, Fenton process, and waste stabilization ponds. The advantages, disadvantages, and techniques used for each treatment process are critically 
discussed. There are many negative impacts associated with wastewater for irrigation as per the previous studies $[27,32]$. Hence it is necessary to focus on minimizing the harmful impacts posed by wastewater before its application in agricultural fields.

\subsection{Target pollutants.}

The definition of a water pollutant varies from document to document. The legislation that regulates water management often defines pollutants according to the issues that the region of concern encounters. In general, water pollutants can be defined as natural debris, industrial, commercial, municipal, agricultural, livestock, or transport-related wastes integrated with water masses. Such waste could contain chemicals, biological materials, petroleum, rock debris and sediments, physical debris of community refuses, heavy metals, and even, in extreme cases, radioactive substances.

\subsubsection{Point pollutant sources.}

In most parts of the world, water resources either located or flow through industrialized or urbanized landscapes receive pollutants from single identifiable origins, termed point sources. In well-developed countries with strict water regulatory legislation and underdeveloped countries with loosely formulated and monitored regulations, the origins of point pollutant emission are inevitable. However, in the former case, extra efforts are made to filter the pollutants adequately before they are released to water bodies, whereas in the latter, they are hardly treated before the effluents are released. Thus, in the latter case, the pollutant origin becomes a pollutant source.

Polluted discharges may reach the water body from the point source via purpose-made or naturally-formed canals, ditches, pipes, conduits and tunnels, fissures, or by vehicles. At harbors or community housing schemes on waterbodies (such as floating communities in South East Asia), pollutants may be directly released into the water bodies from the point of origin.

Although the entrance of pollutants to a water body from a point source is geographically stationary, its effects could be observed even at kilometers downstream. However, due to the definable source origin and the cause of source, enforcement of standards and regulations to control point sources is somewhat doable under ordinary circumstances. Usually, in any given country, a statutory body determines which types and levels of pollutants from a point source could be released to a water mass. For example, the US National Pollutant Discharge Elimination System (NPDES), which operates under Environmental Protection Agency, regulates the water quality of point sources. Several types of point sources are listed in Table 1.

\subsubsection{Non-point pollutant sources.}

Stormwater runoff through mineral and metal mines, agricultural fields, loosely bound soil layers of excavated soil (example for mass-scale construction), municipality waste dumps, etc., and integration into water masses are classified as non-point sources. Compared to point sources, non-point sources could bring similar or even worse content and quantity of pollutants into the water bodies. There are instances where extreme events such as flash floods, hurricanes, and dam bursts transferred massive quantities of pollutants from inland locations to the water masses within a short period [33]. 
In many countries, non-point sources are a higher threat to the well-being of water resources than the point pollutant sources $[34,35]$. The uncontrollable and unpredictable nature of such non-point sources and difficulties in identifying ownership are the two key reasons for the inability of legislative bodies to impose regulatory actions to prevent such sources. Table 1 depicts the classification of several types of non-point sources.

Table 1. Classification of pollution sources.

\begin{tabular}{|c|c|c|}
\hline $\begin{array}{l}\text { Nature of the } \\
\text { source }\end{array}$ & Sources & Major pollutants \\
\hline \multirow{3}{*}{$\begin{array}{l}\text { Industrial point } \\
\text { sources }\end{array}$} & $\begin{array}{l}\text { Petrochemical refineries, automobile service } \\
\text { stations, diesel power stations, metal processing } \\
\text { plants }\end{array}$ & $\begin{array}{l}\text { Petroleum effluents, carbon particles, } \\
\text { chemicals, metal, and heavy metal traces }\end{array}$ \\
\hline & $\begin{array}{l}\text { Paper and pulp mills, printers, weaving and fabric } \\
\text { industry, cloth cleaners }\end{array}$ & $\begin{array}{l}\text { Dyes and toxics, bleaching agents, } \\
\text { detergents, heavy metals, other } \\
\text { chemicals }\end{array}$ \\
\hline & $\begin{array}{l}\text { edible oil plants, cereal, fruit and vegetable } \\
\text { processors, pharmaceutical manufacturers, } \\
\text { wastewater treatment plants, wineries, and breweries }\end{array}$ & $\begin{array}{l}\text { Toxics, organic wastes, dyes, non- } \\
\text { petroleum oil effluents, microbial }\end{array}$ \\
\hline $\begin{array}{l}\text { Agricultural point } \\
\text { sources }\end{array}$ & $\begin{array}{l}\text { Livestock keepers, farms with slaughterhouses, meat } \\
\text { and fish processors, aquaculture ponds, farmlands }\end{array}$ & $\begin{array}{l}\text { Traces of insecticides, pesticides and } \\
\text { chemical manure, microbial, animal } \\
\text { body parts, other organic wastes }\end{array}$ \\
\hline $\begin{array}{l}\begin{array}{l}\text { Small } \\
\text { sources }\end{array} \\
\end{array}$ & $\begin{array}{l}\text { Domestic installations, restaurants, and public toilets } \\
\text { close to water bodies }\end{array}$ & $\begin{array}{lll}\text { Organic wastes, microbial, non- } \\
\text { degradable solid wastes }\end{array}$ \\
\hline $\begin{array}{l}\text { Agricultural non- } \\
\text { point sources }\end{array}$ & $\begin{array}{l}\text { Farmlands under heavy surface runoff water, fish } \\
\text { ponds under floodwater, }\end{array}$ & $\begin{array}{l}\text { Organic wastes (both solid and liquid), } \\
\text { diluted contents of chemicals, and } \\
\text { microbial }\end{array}$ \\
\hline $\begin{array}{l}\text { Mining related } \\
\text { non-point sources }\end{array}$ & $\begin{array}{l}\text { Metal and mineral ores (both usable and abandoned } \\
\text { piles) under heavy surface runoff water }\end{array}$ & $\begin{array}{l}\text { Traces of metal and heavy metal traces, } \\
\text { sediment particles }\end{array}$ \\
\hline $\begin{array}{l}\text { Municipality non- } \\
\text { point sources }\end{array}$ & $\begin{array}{l}\text { Garbage collection, sewage collection, healthcare } \\
\text { waste collection, domestic septic systems, etc. under } \\
\text { flood water }\end{array}$ & $\begin{array}{l}\text { Microbial and pathogens, Organic } \\
\text { wastes (both solid and liquid), oil (both } \\
\text { petroleum and non-petroleum) traces, } \\
\text { metal traces, chemicals, and toxins }\end{array}$ \\
\hline
\end{tabular}

\subsubsection{Removal of pollutants.}

Although the quality issues are not as stringent as those for producing drinking water from already used resources, applying such used water for agricultural purposes needs serious attention. Depending on the types and quantities of wastewater pollutants, both the land and the harvest could be highly contaminated. The land contamination may increase soil toxicity, salinity, and acidity, deposition of sediment layers of rock debris, lime, and other minerals, integration of heavy metals and radioactive substances, etc. Such soil contamination, in turn, affects the agro-harvest as the plants may; undergo growth inhibition, be increasingly exposed to fungal and bacterial diseases and insect attacks, be less productive and mutated. The plants and the crops may contain toxic substances, heavy metals, and radioactive elements [36]. In the long run, the agro-fields that are supplied with untreated wastewater may become unusable for growing any type of commercially valuable plant [37].

Thus removal of pollution through proper water treatment plays an essential role in the reuse of wastewater for agricultural application. Such reuse of water plays a significant role in water-scarce regions, especially in arid and semiarid landscapes.

\subsection{Membrane filtration techniques.}

A number of reasons led researchers to find alternative technologies to replace traditional wastewater treatment methods, such as discharge compliance issues, spatial constraints, and high cost of treatment. Due to its wide range of applications and performance, membrane technology has gathered much attention in this regard [12,38]. Water quality 
standards to suit irrigation depend on Sodium Absorption Ratio (SAR) calculation, adjusted SAR, and Residual Sodium Carbonate (RSC). Measured parameters like electric conductivity, calcium and potassium concentration, and total suspended solids are also important to compare water quality $[39,40]$. Keeping in view the parameters mentioned above, a Micro Filtration (MF) unit was tested in the Kuwait Institute for Scientific Research. MF unit was installed at secondary wastewater stages in Riqqa wastewater treatment plant in Kuwait, a few kilometers away from the Arabian Gulf, to treat its effluent. MF unit proved to be a very effective way of removing impurities from wastewater [41]. Chemical analysis of effluent also verifies that the MF system shows significant reductions in Chemical Oxygen Demand (COD), Biological Oxygen Demand (BOD), Total Suspended Solids (TSS), and Total Bacterial Count (TBC). Consequently, wastewater quality was improved significantly to suit irrigational applications. However, some recent studies show that with emerging demands for a better quality of treated wastewater for irrigation and other purposes, new multi-parametric quality indices may be required in the future [42].

From Visvanathan et al. [38] to Ezugbe and Rathilal [43], two decades of extensive work could be found in the literature where various technologies are compared for their merits and demerits, considering effluent quality as one of the parameters. Applications of the membrane in aerobic and anaerobic conditions have been discussed in detail in these studies. The membrane used as a liquid/solid separator was the focus of the Ezugbe and Rathilal [43] study, which is a key to achieving effluent of desired quality. They have also conducted an economic assessment of using these technologies to check the viability of the techniques.

Another example of membrane technology that has successfully been applied in water treatment is the membrane bioreactor (MBR) system. This process involves a perm-selective membrane such as microfiltration or ultrafiltration integrated with a relevant biological process. The operation of solid-liquid separation is done through the selected membrane. There are several versions of the MBR. However, the most commonly applied techniques are the gravity-driven method and the pressure-driven method. The gravity-driven method (also called the vacuum method) engages flat-sheet membranes immersed in the wastewater (bioreactor or sequential membrane tanks). In the pressure-driven method, specifically made, an in-pipe cartridge of membranes is fixed to the bioreactor, typically from external means $[38,44,45]$. MBRs are mostly applied in Japan, the US, Germany, UK, and France. This technology has been limited to situations requiring good quality treated water because of economic concerns [46]. With an increase in membrane production, a reasonable reduction in the treatment cost of this system has been observed in recent years $[12,15,44]$. It is expected that membrane technology will become competitive with other conventional technologies economically.

Microbial Fuel Cell (MFC) technology was applied by Abourached et al. [11] to treat wastewater before the application in irrigation. The study was conducted in semiarid regions of California. The untreated wastewater produced during many industrial activities such as food processing cannot be directly used for irrigational purposes as it may seal soil pores through bio-film. The analysis showed that MFC technology is a viable option to reclaim wastewater that meets the irrigation requirement [47]. The application of treated wastewater provides an affordable way for its disposal as well.

In the context of decreasing freshwater availability, the European Union (EU) initiated a project SAFIR to help farmers solve problems related to the application of poor quality water for irrigational purposes. Under the project, new prototypes of devices for treatment were developed so that wastewater produced from industries and small communities could be 
applied to the field safely. Irrigation technologies and strategies were combined with water treatment technologies to get a flexible system with integrated management. It is a big challenge to formulate strategies and apply techniques that allow the water of lower quality to be used for irrigation without affecting the yield and fruit quality of the crop. A small-scale pressurized membrane bioreactor was tested in the study. Results presented include the testing of heavy metal adsorption materials and commercially available gravel filters. Pressurized membrane bio-booster removed $99.99 \%$ of Escherichia coli present at the inlet. The removal success of total coliform was $98.52 \%$. All samples met WHO quality standards [48] in the year 2008. MBR removed 99\%, 93\%, 97\%, 82\% of lead, copper, chromium, and arsenic, respectively. The field treatment method (FTS), with its complete setup, proved to be very effective in treating fecal contamination. If gravel filters and heavy metal removal devices are used solely, the results significantly decrease their capacity to remove microbial contamination. $[47,49]$.

Seawater desalination can make a significant contribution to overcoming water scarcity by providing water for irrigation. Seawater Reverse Osmosis (SWRO) has become the leading technology in seawater desalination because it saves more energy than thermal desalination. However, from a broader perspective, high cost and energy consumption are two major barriers to its implementation on a large scale [50,51].

Strict standards for chloride and boron irrigation water have made desalination for irrigation more energy-consuming than desalination for other uses. Reducing energy consumption in this process will decrease the cost of treatment and eventually improve SWRO sustainability [51,52]. Shaffer et al. [53] integrated reverse osmosis process SWRO with forwarding osmosis for desalination to achieve the desired concentration of boron and chloride in irrigation water while conserving energy. The integrated process is more sustainable than the conventional practice of using SWRO. It was reconfirmed through the experiments done by Davenport et al. [54].

\subsection{Coagulation-flocculation.}

The process of coagulation-flocculation aims to treat wastewater effluents and improve water quality indicators to meet the requirements of standards and guidelines established for water used for irrigation [55,56]. The coagulation-flocculation process utilizes chemicals and flocculants to neutralize the charge on the particles of wastewater effluents, which aids in the agglomeration of colloidal particles that can easily remove sedimentation and filtration [57]. In the chemical coagulation, the suspended solids can be partially removed by pre-treatment using poly-aluminum chloride (PAC) and a polymer that can aid coagulation $[55,56]$. The coagulant is added to destabilize the colloidal particles in the suspension by reducing the repulsive forces. These particles are agglomerated by flocculent addition to form solid lumps that can be settled and removed by gravity sedimentation or filtration. During the process, the surface charges are reduced, and complex hydrous oxides are formed. This process leads to undesired pollutants being trapped inside the flocculent compound suspension or insoluble pollutant precipitates being formed. This process is instantaneous and particles formed are very small in size [57]. The process of coagulation and flocculation for the water treatment is shown in Figure 1, of which the concept was adopted from Howe et al. [58].

The chemicals and their concentrations are selected utilizing laboratory jar-test apparatus. Wastewater samples are added to the jars, and the selected quantity of coagulant is added and rapidly mixed. The flocculent is added next. The particles are then allowed to settle 
for 45 minutes. The supernatant is then analyzed to determine the effects of coagulant and flocculent [59]. Due to its oxidative and disinfectant properties, Ozonation is sometimes combined with the coagulation-flocculation process to considerably reduce the physicochemical and microbial pollutants in wastewater effluents, making it effective for reuse in agricultural irrigation [60]. The removal efficiency of coagulation-flocculation technology given by Zaleschi et al. [61] and Omar [62] is given in Table 2.

The limitations of the various physiochemical and hygiene indices of the treated wastewater used for the irrigation are given in Table 3.

Coagulation characteristics differ from pollutant to pollutant [63]. Thus, a comprehensive study should be conducted on the wastewater composition before adopting a given case coagulation technique. Failure to do so may result in the entire process being inefficient and ineffective.

Table 2. The removal efficiency percentages for quality of water (Zaleschi et al. [61] and Omar [62]).

\begin{tabular}{l|c} 
Water Quality Indicators & Removal Efficiency $(\%)$ \\
\hline Suspended Solids & $50-70$ \\
\hline Turbidity & $30-50$ \\
\hline Total Nitrogen & $>60$ \\
\hline Nitrates & 0 \\
\hline Chemical Oxygen Demand & $>60$ \\
\hline Biochemical Oxygen Demand & $>60$ \\
\hline Phosphates & $>60$
\end{tabular}

Table 3. Physiochemical and hygiene limitation for irrigation (Wang et al. [63]).

\begin{tabular}{l|l} 
Index & Limit \\
\hline BOD $_{5} /(\mathrm{mg} / \mathrm{L})$ & $<20$ \\
\hline COD $_{\mathrm{Cr}} /(\mathrm{mg} / \mathrm{L})$ & $<100$ \\
\hline Suspended Solids $/(\mathrm{mg} / \mathrm{L})$ & $<30$ \\
\hline Total Nitrogen/(mg/L) & $<30$ \\
\hline $\mathrm{pH}$ & $6-9$
\end{tabular}

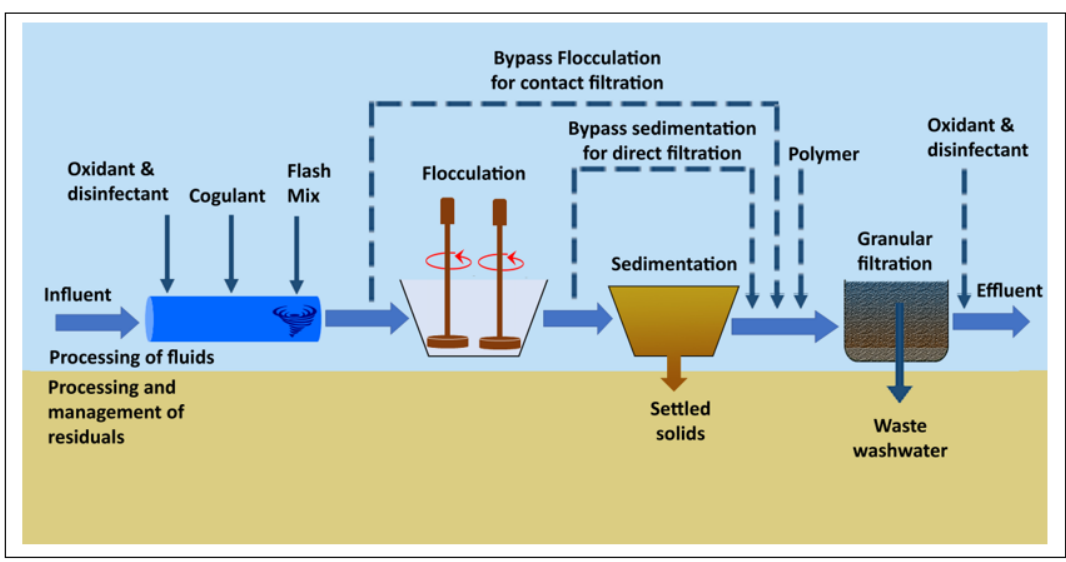

Figure 1. Coagulation and flocculation systems for wastewater treatment (The concept was adopted from Howe et al. [58]).

\subsection{Electrocoagulation.}

In electrocoagulation, an electric current is allowed to flow between two electrodes. The anode material undergoes electrolytic oxidation, and coagulant is produced in situ [64]. According to Secula et al. [65] and Zaleschi et al. [61], this wastewater treatment method produces the disinfection agents within the electrochemical cell. If the value of total dissolved solids (TDS) in wastewater is high, additional electrolytes are not needed as they will aid in the passage of current in wastewater $[64,66]$. Whereas both iron and aluminum electrodes can be used for this purpose, the iron electrode is proven to be more efficient and provides better 
water quality [61,67]. In electrocoagulation, secondary pollutants are not formed, and the reactive agents are produced in-situ [64,66].

As mentioned in several studies [66,68], the basic principle of adding iron and aluminum ions for water treatment is similar for both chemical coagulation and electrocoagulation processes. The way these metallic ions are introduced in the wastewater establishes the primary difference between these processes. According to Riera-Torres et al. [69], Zaied et al. [67], and Zaleschi et al. [61], the reagents are directly added to the wastewater in the chemical coagulation technique. The metallic cation is produced by the oxidation process at the electrode for electrocoagulation, which helps produce metal ions. The coagulation of particles in electrocoagulation is improved as the pollutants are attracted towards the anode, while the cathode produces hydrogen bubbles that increase the formation of flocs of precipitates that can be easily separated. The flocs formed by electrocoagulation are stronger than the flocs formed during the process of chemical coagulation.[57].

Studies have revealed that electrocoagulation and chemical coagulation help remove the oxidable chemicals from wastewater [70,71]. In contrast to coagulation, the electrocoagulation process is more efficient in terms of removing COD at the rate of $83 \%$ of $\mathrm{Fe}$ (III) and $72 \% \mathrm{Al}(\mathrm{III})$ [72]. Whereas in chemical coagulation, the removal rate is $47 \%$ of $\mathrm{Fe}(\mathrm{III})$ and 35\% Al(III) [72]. Hence, COD values obtained using electrocoagulation are much lesser than those obtained using a similar coagulant amount for coagulation. Considering the improvements in water quality indicators after wastewater treatment using coagulation and electrocoagulation techniques, it can be suitably applied in various applications such as irrigation of the land for agriculture [61].

\subsection{Batch reactor.}

The main purpose of treating wastewater for irrigation is to remove some materials such as ammonium and nitrates that could impact remove some materials such as ammonium and nitrates could impact plants and soil $[73,74]$. Reactor treatment cannot be used independently, and most often, it has been used with chemical coagulation or membrane filters. Lin and Cheng [75] proposed an experimental investigation that could be conducted using SBR and chemical coagulation. It includes poly-aluminum chloride (PAC) and a polymer for wastewater treatment in irrigation. A beaker can be filled with 1 liter of wastewater and prepared for irrigational usage. It is essential to filter wastewater to remove larger solid materials before using the SBR. It is advised that PAC and polymer should be mixed separately, and the chemical reaction is allowed to take place for half an hour [75]. The suggested method has four steps of SBR, starting with wastewater influent, sludge settling due to PAC and polymer, aeration, and finally discharge of water. SBR method can also be applied for greywater treatment. This method can also be used efficiently to remove organic matter and ammonium oxidation [73,74].

In Mediterranean countries, wastewater coming from olive oil farms is the biggest threat to the rivers. It is necessary to treat the water discharged into the Mediterranean and reuse the water for irrigation. Many researchers have studied this concern, and various suggestions have been presented. An efficient solution would be the use of the Fenton process. The main aim is to remove or reduce harmful materials such as $\mathrm{H}_{2} \mathrm{O}_{2}, \mathrm{pH}$, and iron ions to reuse wastewater for irrigation [76]. It has been suggested that strong acid cations exchanges such as resin and sulfonic acid could reduce harmful materials from the wastewater [77]. Organic matter also can be removed by using hydrogen peroxide found in the $\mathrm{FeCl} 3$ catalyst. 
Stirred batch reactors with controlled temperature were used as a container as the temperature is very important for chemical reaction and settling the unneeded materials [78]. $\mathrm{Fe}$ (II) for the Fenton process and $\mathrm{Fe}(\mathrm{III})$ for the Fenton-like process will act as catalysts for decreasing $\mathrm{H}_{2} \mathrm{O}_{2}$ and $\mathrm{OH}$, which helps in reducing COD [79]. The chemical reaction in the Fenton process has been described in equation (1) below.

$$
\mathrm{Fe}^{2+}+\mathrm{H}_{2} \mathrm{O}_{2} \rightarrow \mathrm{Fe}^{2+}+\mathrm{OH}+\mathrm{OH}^{-} \mathrm{Fe}^{2+}+\mathrm{H}_{2} \mathrm{O}_{2} \rightarrow \mathrm{Fe}^{2+}+\mathrm{OH}+\mathrm{OH}^{-}
$$

Because of the time-consuming chemical process of Fenton, Fenton-like has been suggested due to faster reactions between materials [76], where the chemical reaction is described in equation (2);

$$
\mathrm{Fe}^{3+}+\mathrm{H}_{2} \mathrm{O}_{2} \rightarrow \mathrm{Fe}^{2+}+\mathrm{O}_{2} \mathrm{H}+\mathrm{H}^{+} \mathrm{Fe}^{3+}+\mathrm{H}_{2} \mathrm{O}_{2} \rightarrow \mathrm{Fe}^{2+}+\mathrm{O}_{2} \mathrm{H}+\mathrm{H}^{+}
$$

Other practical ways of treating wastewater for irrigation are the use of physical and chemical treatments. To achieve this chemical coagulation, the Fenton reactor and ion exchange have been adapted. Figure 2 graphical presents the process of the treatment. All three steps shown in Figure 2 are conducted in the batch reactor due to their suitability for this process over the continuous mode. For chemical materials, PAC and polymer have been used due to the efficiency of these chemicals for settling the organic matter. Different mixes have been used, as shown in $4 \mathrm{~b}$. It is suggested that PAC and polymer are mixed separately, and each is allowed to remain for 20 to 40 minutes. The water should be allowed to stay for approximately 1 hour to settle in the sedimentation tank. The wastewater after $\mathrm{pH}$ control is carried to 4 tanks of the same size for Fenton reaction, and hydrogen peroxide $\left(\mathrm{H}_{2} \mathrm{O}_{2}\right)$ and ferrous sulfate $\left(\mathrm{FeSO}_{4}\right)$ are added successively [55].

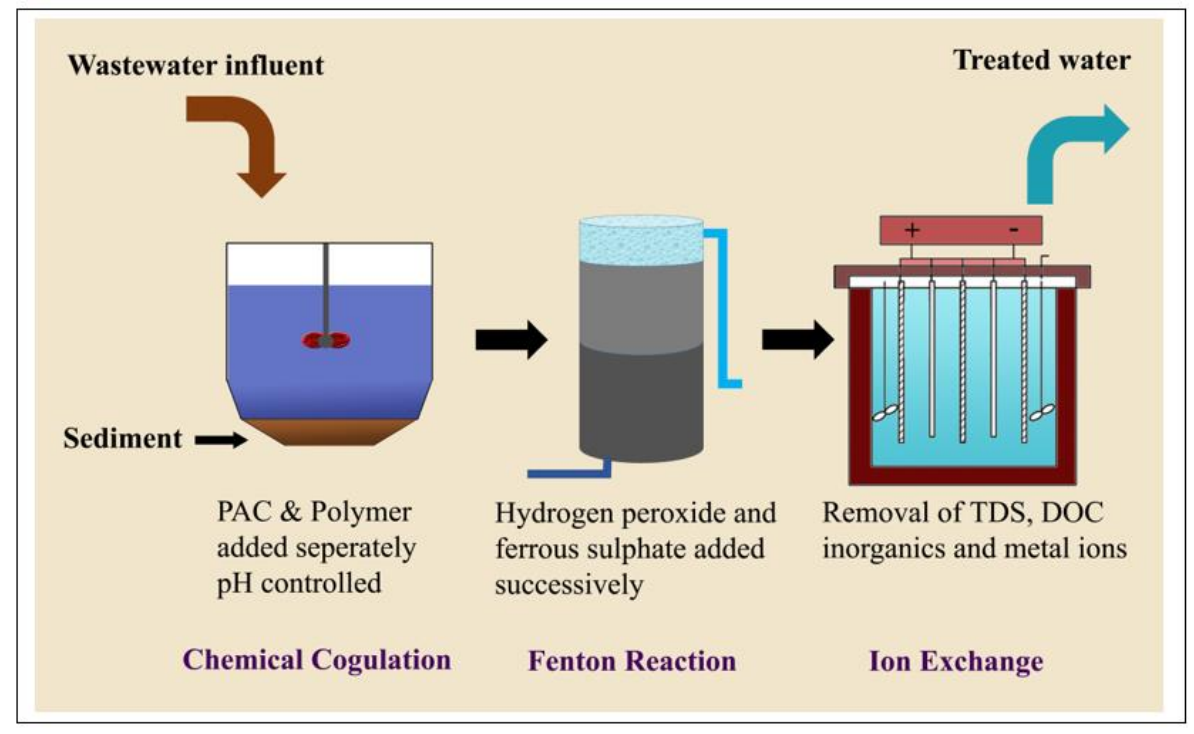

Figure 2. The schematic diagram for Fenton Process.

Ion exchange is used to extract inorganics and metal ions and lower total dissolved solids (TDS) [55]. The method, which employs a combination of anode and Fenton oxidation coagulation (AFC), can be applied to remove the dissolved organic carbon (DOC) from wastewater. In this method, the cathode is separated from the anode by cation and anion exchange membrane (CEM and AEM) [79]. The application of solar energy for the Fenton process and solar UV is another solution for increasing urban wastewater treatment efficiency by removing fecal bacteria. The process is called solar Photo-Fenton that has a high impact on $\mathrm{pH}$, affecting the iron salt precipitation, which is given in equation (3) [17]. 


$$
\mathrm{Fe} \mathrm{OH}^{2+}+h v \rightarrow \mathrm{Fe}^{2+}+\mathrm{OHFeOH}^{2+}+h v \rightarrow \mathrm{Fe}^{2+}+\mathrm{OH}
$$

Removing COD and BOD with reverse osmosis (RS) membrane is another use of solar Photo-Fenton $[17,80]$. The process also can be conducted for fungi which are a big concern for the farming industry.

\subsection{Wastewater stabilization ponds (WSP).}

The most commonly used technologies for wastewater treatment for their future application in agricultural fields are lagoons or wastewater treatment ponds (WTPs) [81]. They are shallow basins through which there is a continuous flow of wastewater. The treated wastewater can be acquired after a certain retention period that may span from several hours to several days [82]. Mansouri and Ebrahimpou [83] described WSPs as basins designed to treat wastewater in the presence of aerobic and non-aerobic bacteria algae. The WSPs uses the photosynthetic reaction of algae and aquatic plant to form gaseous oxygen to biodegrade the organic matter by bacteria [82] aerobically.

According to the Mcnaughton et al. [84] report in New Zealand and the United States, WSPs are used to treat more than half of the effluent quantity being produced. Similarly, Noyola et al. [85] pointed out that in the Dominion Republic, Mexico, and Brazil, WTPs are the most common treatment methods used. A detailed discussion in this regard can be found in Verbyla and Mihelcic [81].

This method can also be used in combination with other methods such as chemical coagulation and batch reactors. Combined WSPs were used to reduce the organic load and helminth eggs in wastewater samples of Morocco. The method has been evaluated by checking water and soil for chemical and bacteriological parameters per the WHO guidelines. The outcomes show that the method is highly efficient in water treatment that the outflow is suitable even for crops such as potato and lettuce that require a supply of high-quality water [86]. This outcome has been reconfirmed repeatedly during the last decade $[87,88]$.

WSPs are a combination of anaerobic, facultative, maturation, and high rate algal ponds that can either be arranged in series or parallel depending on conditions. The function of facultative and anaerobic ponds is primarily to remove Biochemical Oxygen Demand. The maturation ponds remove suspended solids and pathogens. However, some of the pathogens and suspended solids are removed by facultative and anaerobic ponds. Likewise, some of the BOD5 is removed through maturation ponds [82].

Verbyla et al. [89] highlight that the WSPs are the most effective systems for treatment as they work efficiently and remove pathogens within minimal maintenance cost. According to WHO guidelines, certain criteria have to be met before wastewater can be used for irrigational purposes. WSPs can remove E. coli per WHO guidelines. WSPs also influence bacteria such as Salmonella spp and Shigella spp [90].

Anaerobic ponds are usually utilized to treat high organic content wastewater. In the anaerobic pond, bacteria biodegrade the accumulated suspended solids and BOD5, resulting in the formation of biogas methane that can be used to produce heat and electricity. Facultative ponds are the most common types of WSPs used for the treatment of wastewater. In this process, the bacteria utilize the oxygen formed by algae to biodegrade organic matter. Maturation ponds are WSPs used to enhance further the quality of treated effluent discharged by facultative ponds. It is usually designed in series with facultative ponds. The discharge from the facultative ponds contains algal cells, resulting in a concentration of suspended solids and 
color that is unsuitable for the final discharge. High rate algal ponds are provided with aeratorsmixer to recirculate the WSP contents and produce treated wastewater or algal biomass [82].

Verbyla et al. [89] stated that the accumulation of sludge influences WSP performances. Based on the study by Oakley et al. [91] and further discussed by Verbyla et al. [89], the sludge removal cost is not included in the initial operation and maintenance cost, which may lead to future sustainability problems. Sludge removal from primary WSPs requires high maintenance costs after every 2-15 years. The period of maintenance depends on the design of the system and the solid loading rate. According to several studies [81,92,93], WTPs have an advantage due to the simplicity of construction, operation, and maintenance cost. Polprasert [94] and Polprasert and Kittipongvises [82] indicated that the treated effluent could be used for land irrigation purposes. The treated effluents have significantly reduced Biochemical Oxygen Demand at 5 days (BOD5), nitrogen content, metals, phosphorus, suspended solids, and pathogen content.

In the WSP, the sidewall bacterial bio-film and the suspended bacteria inside the pond help remove BOD5. The suspended solids (SS) are removed due to settling at the bottom of the pond. The SS content may also be reduced by adsorption on algal cells. The algal cells form larger particles that can then be removed by sedimentation. Several studies $[82,95,96]$ have stated that in WSPs, the algal biomass removes nitrogen and phosphorus. Heavy metals are removed by precipitation. Exposure of facultative and maturation ponds to sunlight and UV light causes the pathogens in wastewater to become inactive. High $\mathrm{pH}$ during algal photosynthesis is also responsible for the reduction in the pathogens present in the effluent.

Not all complicated wastewater effluents could be treated for irrigation using the WSP system. It is suggested that wastewater treatment from chemical industries should be done using other methods rather than WSPs [97]. Organic compounds, mercury, and chlorides are the primary materials that can be found in the industry, which might not be removed with WSPs [98].

Mara and Pearson [99] proposed a hybrid waste stabilization pond-wastewater treatment reservoir system. The objective of the study was to treat effluent to produce microbiologically safe water for crop irrigation. The wastewater was treated in facultative and anaerobic ponds. Maturation ponds were also used for treatment in some cases. Effluent from WSP was used to fill wastewater storage and treatment reservoir (WSTR) during non-irrigation season. WSP effluent was used for restricted irrigation in irrigation season, while WSTR contents were used for unrestricted irrigation. As a result of the WSP-WSTR system, the application of treated wastewater irrigated land area increased significantly. WSTR emerged as a financially viable treatment option, with an internal return rate of $58 \%$.

Wastewater, after proper treatment, can be used as irrigation water and as liquid fertilizer. A study was conducted to examine WSP technology as a potential source of producing high-quality water for irrigation and evaluate the effects of applied water on maize growth. The application of treated wastewater that is rich in nitrogen $(21.02 \mathrm{mg} / \mathrm{l})$, phosphorus $(3.49 \mathrm{mg} / \mathrm{l})$, and potassium $(6.66 \mathrm{mg} / \mathrm{l})$ resulted in a significant increase in plant height, leaf area, and crop production [100].

Melián et al. [101] analyzed dissolved biological oxygen demand (BOD), total organic carbon (TOC), and NH4-N at seven different points in a pond-wetland treatment system for wastewater to check the efficiency of its constructive elements. The wetland consists of free water wetlands, horizontal-flow stone filters, and a subsurface-flow wetland. Parameters calculated at each constructive element include the elimination and elimination efficiency. The 
pond achieved the highest BOD elimination when higher BOD loads were applied. The highest BOD elimination efficiency, however, was achieved by the stone filters. The quantity of NH4$\mathrm{N}$ eliminated was largest in the horizontal subsurface flow constructed wetland and the pond, although the stone filters attained greater elimination efficiencies than the other elements. The results demonstrated high bacterial activity in stone filters and high oxygenation in pond and surface flow wetlands. Therefore, the study suggests combining subsurface flow wetlands with the short horizontal surface for NH4-N elimination.

\subsection{Risks associated with non-treated wastewater irrigation.}

Wastewater can be regarded as a renewable resource and effluent from the integrated natural resource management viewpoint $[26,28,102]$. The percentage of contaminants in treated wastewater depends on the source of wastewater and the method of refinement [103]. Wastewater usually comes from industrial effluent and domestic sewage. These sources are rich in pollutants, heavy metals, and pathogens, which may negatively affect the environment and potentially affect animal and human health [104]. High levels of metals, volatile or semivolatile compounds, and metalloids are present in industrial effluents, whereas domestic sewage has a very high concentration of pathogens and microorganisms [26,32].

According to WHO [105], Hamilton et al. [106], and Srinivasan and Reddy [104], food produced using wastewater irrigation is consumed by at least $10 \%$ of the population in the world. In many countries, consumers, farmers, and government agencies are ignorant of the harmful effects of irrigating lands using wastewater without proper treatment [26,32]. WHO [105] and Elgallal et al. [103] point out that industrial water and municipal wastewater are mixed and used untreated or partially treated in developing countries.

Even if wastewater used for irrigation is a beneficial source of plant nutrients and organic matter, many associated risk factors should properly be addressed before its reuse. Some risk factors may have short-term effects like pathogens, whereas others may have longterm impacts, such as salinity which increases with continuous application in the irrigated field [32]. A study by WHO [105] revealed that the effects of these risk factors depend upon their solubility, concentration, inherent toxicity, rate and regularity of wastewater application, crop type, targeted crop yield, properties of soil, condition of groundwater aquifer, climate scenario, wastewater treatment methods, and the farmer's socio-economic status. Hence, the use of wastewater for irrigation should carefully be managed to reduce the negative impacts to a higher degree.

\subsubsection{Effects of heavy metals.}

When utilized by humans, heavy metals contaminated food crops are the primary source of toxic metals into the body. After several years of exposure to such crops, the harmful effects of these toxic substances are revealed [104]. Recent studies in China reveal that even the national environmental quality standard for soils [107] has not been able to meet its intended objectives effectively in controlling the levels of heavy metals in soil [108]. The studies carried out by Hamilton et al. [106], WHO [105], Chen et al. [109], and Khan et al. [110] indicate that the heavy metal cadmium, due to its high mobility characteristics, poses major harmful effect on human health. It is bio-available to plants, even at a decreased concentration, and imparts risk to human health $[103,111]$. Studies have pointed out that around $45 \%$ of land irrigated using wastewater in China is polluted with heavy metals in China [104]. It is suggested that 
wastewater irrigation should not be encouraged if the heavy metal concentration in the food crops is higher [26,30,31,111].

\subsubsection{Effects of nutrients.}

A high concentration of nutrients (in nitrogen, potassium, and phosphorus) is present in wastewater. Their concentrations vary depending upon the treatment method used for wastewater and its source [103]. The nutrients in this water may be used for food crops and help plant growth [32]. However, as stated by WHO [105], Hamilton et al. [112], Qadir and Scott [113], and Chen et al., [109], the excess of nutrients, especially N \& P, may have substantial negative effects on the ecological systems [114].

\subsubsection{Effects of pathogens.}

Pathogenic micro and macro organisms in wastewater used for irrigation threaten to directly or indirectly with the wastewater. [104,115]. According to WHO [48], pathogens can live for a very long time in soil or on the surfaces of crops and can be transmitted to humans easily. Domestic sewage consists of organic matter in high amounts and pathogenic microorganisms such as bacteria, protozoans, and viruses [32]. Bacteria, helminths, trematodes, protozoa viruses may impose health risks for those in contact with this wastewater, for example, farmers and those consuming the crops irrigated using this wastewater [115]. Humans consuming these products are vulnerable to diseases like typhoid, dysentery, vomiting, malabsorption, and diarrhea [32].

\subsubsection{Effects of salts.}

Fattal et al. [116] indicated that domestic sewage includes a considerably high quantity of salt in their study. Land irrigation using treated wastewater induces land salinity, land sealing, and increased accumulation of sodium compounds. These factors may lead to excessive runoff and land erosion [32]. Simmons et al. [117] suggested that the long-term salinity problems are due to poor irrigation management and improper drainage systems in soils. In arid and semiarid zones, the salts are accumulated due to lack of rainfall and excessive evaporation rates. Wastewater from many industrial sources could carry water-soluble anions such as chlorides, nitrates, sulfates, etc. They may also contain cations such as sodium, magnesium, potassium, etc. Both of these ions may have adverse impacts on photosynthesis, respiration, and assimilate distribution, leading to wilting, drying, stunting, or destruction of the organs [118]. The salt deposits could also change the soil's physicochemical properties and microbial ecology that could be very unhealthy for the well-being of the plants $[115,119]$.

\subsection{Effects of irrigation with treated wastewater.}

Despite the many benefits of using treated wastewater for irrigation, several issues and challenges are incorporated with such practice. Recent studies have emphasized that sorbents used for removing chemical toxins and metals should not, in turn, introduce environmentally hazardous materials into both landmasses and the atmosphere [120,121]. Thus, it is always emphasized to use green sorbents in the treatment processes to avoid adding aggressive materials into the environment. Over the years, the accumulation of hazardous sorbent 
remnants may cause a similar degree of damage to the agricultural lands as the pollutants they intend to remove do.

Although wastewater treatment plants could filter out many pollutants, the effluent may still contain many chemicals of organic nature. Helmecke et al. [37] and Piña et al. [122] show that these chemicals transfer to the soil from the treated water and consequently be transported into multiple parts of the commercial plants. The accumulation of such toxins in edible leaves, cereals, fruits, and vegetables, could lead to serious contamination of the food chain.

Piña et al. [122] and Rizzo et al. [123] confirm that both treated water irrigated landscapes and wastewater treatment plants could be the breeding grounds of antibioticresistant bacteria and genes, which could make a serious threat to the human environment. At present, extensive research has been underway to investigate the gravity of this issue $[124,125]$.

As per the above discussion, the exact risks, in this case, are not easier to evaluate with current knowledge. It may have long-term impacts, not only on the irrigated landscapes but on nearby aquafers. Thus, it is recommended not to use treated wastewater for irrigation when the agricultural fields are near drinking water wells $[32,126]$. The use of wastewater for irrigation is helpful from the viewpoint of added soil fertility and increased plant growth [127]. Therefore, proper control measures should be established to eliminate the harmful effects of wastewater irrigation while taking advantage of the natural plant nutrients $[126,128]$.

\subsection{Sustainability of wastewater treatment for irrigational applications.}

According to the United Nations World Water Development Report released in 2017 by UN-Water, a Geneva-based inter-agency coordinating body of the UNO efforts in preserving freshwater supply, $80 \%$ of the global wastewater generated in human activities is flown back untreated to the environment. What if at least a small part of this water is treated and reused for agriculture? The answer to this question relies on the sustainability of the water treatment method that will be applied in purifying the wastewater.

In a manufactured environment, water is used for several purposes with a regiondependent priority order; however, the top of the list is always given to the potable water: a. Water for human consumption; b. Water for domestic and community usage (non-potable applications); c. Irrigational applications in the agriculture and livestock industry; d. Factory usage; e. Mining and mineral processing; f. Other commercial applications

There is always a competition for available water among the above applications, which extends even into legal suits, tribal fights, diplomatic conflicts, and even full-scale state-state wars. The level of competition among the parties that acquire water depends on the extent of the scarcity of fresh water in a given landscape. Usually, people in arid and semiarid regions experience limitations in accessing freshwater. However, aridness is not the sole reason for the lack of water available for the purposes mentioned above. High levels of salinity, acidity, sulfur, magnesium and calcium, heavy metals, toxics such as dissolved ammonia, and radioactivity are factors that make available water unusable for human applications. As the available runoff or groundwater levels diminish (increased water scarcity), the concentration of these factors may increase. Thus, regions of water scarcity are most often linked with aridness and the factors that make the available water unsuitable for most of the applications.

The sustainability of wastewater treatment methods adopted for irrigational purposes in a given landscape depends on this competition among several societal sectors for the available freshwater. The actual need for water for a given purpose needs to be weighed with 
the following parameters, on which the private sector or government decides to invest in wastewater treatment: a. The quality of treated water required for the given purpose (meeting international/national standards); b. Cost of the method that will decide the cost that the enduser should bear; c. Space requirement for water treatment; d. Time to produce clean effluent; e. The complexity of the process (requirement of skilled operators); f. Disposal of extracted pollutants;

As it is obvious, all the above are interrelated. For example, the time and complexity of the process and the disposal of contaminants directly influence the project cost. And the cost is directly proportional to the level of stringency of the statutory bodies that impose the quality control standards of the effluents. The permissible levels of pollutants in the treated water (point a) depend on the region. The maximum pollution contents (usually given per unit volume of water) are given in the national standards and codes of the respective countries of states. They have also been discussed in detail in several recent publications $[71,129,130]$.

The success of the wastewater treatment for irrigation finally depends solely on the willingness of the end-user to acquire the reclaimed water for irrigational purposes; most often, there are only two factors that the end-user will take into account; the cost of reclaimed water unit, compared to that of an unused water unit, and socio-psychological effects such as the fear of contamination and the yuck factor.

Even in well-developed countries, the farmers pay great attention to the cost per unit volume of reclaimed water before they afford such [10,131]. In the US, regions of no water scarcity, farmers, on average, expect reclaimed water to have $20 \%$ of the cost of freshwater to opt for accessing treated wastewater. However, the demand for reclaimed water increases as the water scarcity aggravates. There may be landscapes where the only option for the farmers to sustain their industry is the use of reclaimed water for irrigation.

From the point of view of the farming communities, there are two negative effects of irrigating with reclaimed water. One such issue is the fear of getting the farmlands contaminated with chemicals and pathogens by treated wastewater [132]. This is not a wrong misconception, as per the discussion in section 3.8. The other issue is the yuck factor, a psychological effect due to the influence of instinctive responses against new technology, which may also refer as technophobia [23,133,134]. Yuck factor may arise due to various reasons, and in irrigation, it is the repugnant sentiment of using once used water for purposes such as toilet flushing and hospital cleaning. The surveys show that rather than farmers themselves having this psychological aversion, their major concern is the rejection of their farm products by the consumers labeling their brands on the shelves as wastewater-generated products [23]. The impact of such public perceptions is higher for small-scale farmers whose products are directly transferred to the local market under a recognized brand name than for large multinational companies whose products are not usually identified by the consumer by their origin.

Wastewater treatment is a method for irrigational applications that is sustainable only if the actual need for water for the purpose has a clear advantage over the above factors, that depends on secondary effects, as it has been discussed. It should be noted that both the significance of the requirement of water and the six parameters are case dependent; thus, it is not possible to generalize the validation of the wastewater treatment methods for irrigation, which can be used as a ready reference. Thus, the sustainability of the water treatment method should be evaluated on a case-by-case basis, and this paper helps to find the significant parameters for doing such evaluation. 


\section{Future Trends and Challenges}

It should be noted that both the rapid increment in population density in many parts of the world and the global climate change seemingly leading the world to acute water scarcity for the consumption of living beings and cultivation of crops. The first factor, human population expansion, is somewhat predictable, but the second, the global climate variation, is not that easily forecasted. It is estimated that by 2050 the gross food production in the world should be doubled the 2025 output to feed the exploding population [4]. Such a process will demand a massive volume of irrigational water. Even at present, over 15 million cubic meters of untreated water out of various man-intervened processes are released to agricultural lands causing the soil to be contaminated with heavy metals, metal salts, toxic chemicals, pathogens, and even excessive amounts of calcium sediments [4]. Unless this practice is not halted, the accumulation of pollutants in the soil may lead to the agro-landscapes becoming unsuitable for cultivation or the crops becoming unsuitable for human/livestock consumption.

Another issue related to water treatment is the disposal of waste products collected in the water treatment processes. A few examples are salts collected in treating brackish water, heavy metal/ toxic chemical contaminated sediments accumulated in treating factory effluents, emission of greenhouse gases, and fumes of bad odor in the treatment process of mostly biologically contaminated effluents $[111,126,135]$. Safe disposal of such outputs also yields energy in various forms, including transportation. Therefore, developing a national framework for wastewater treatment in a given country is not simple. It needs careful consideration on stockpiling of wastewater and/or stormwater, financial cost-benefit analysis, implications of energy consumption, emission of various unfriendly gases to the environment, etc.

The overpopulated and over-utilized landscapes, and unhygienic and environmentally unfriendly practices, have led many under-developed countries to encounter a more severe shortage of agro-water than developed countries [12]. Therefore, both the advancements in water treatment technologies and the cost-benefit analysis are much needed for these communities than rich nations, for the safe balance of the total global environment. Gukelberger et al. [12] have proven that low cost-effective wastewater treatment methods could practically be integrated into such low-literacy communities with proper planning. It is also interesting to note that in such overpopulated landscapes, especially in municipality areas, dual-beneficial projects can be implemented, such as bioreactors where wastewater treatment could generate not only irrigational water but biogases as well that could cater to the energy needs of the society $[15,28,47]$.

The concerns of the quality of the reused water for both hygienic and environmentfriendly usage demands better quality assurance procedures continuously $[8,40,136]$. Thus, one must go beyond the existing standard practices in defining precise quality control indices and implementation methods [62].

Manual quality control methods will not be adequate to measure such vast numbers of parameters and take consequent decisions that should be prompt or long-term. We propose intelligent algorithms for automation and control, remote sensing techniques, optimized decision-making-action logic trees, etc. be developed and applied in the future at various stages of water treatment, release, and consumption. In such a scenario, smart sensors, drone technology, artificial intelligence-based algorithms, machine learning, deep learning, and IoT will be essential to fulfill future expectations. It is also recommended to use solar PV energy for electrical energy extensive treatment processes such as electrocoagulation, where the solar 
panels could be implemented on the wastewater pond itself $[66,67]$. Such energy systems will significantly reduce emissions due to black and brown power sources and could efficiently be applied in tropical countries where daylight is ample.

\section{Conclusions}

The present study was conducted to investigate the use of wastewater for agricultural and irrigational purposes. In recent decades, sewage generated by domestic, industrial, and commercial sources has dramatically increased. The lack of availability of clean water, especially for arid countries, is a significant concern for farmers, agricultural scientists, and government agencies. The reclamation of wastewater to make it suitable for irrigation has decreased the wastewater disposal issues and has decreased the wastewater disposal issues and has decreased the wastewater disposal issues and has also reduced water scarcity problems. Before its application in agricultural fields, the treatment of wastewater is mandatory to make it suitable for humans and the environment in the current trends of exploding population density and changing climate. The contents of this study can be applied in developing policies, guidelines, and frameworks for the conversion of wastewater to suit irrigation.

Various treatment methods were reviewed in the paper that can be utilized for wastewater conversion. Each method has its advantages and disadvantages. Compared to other methods, membrane filtration is an effective method for achieving good water quality. However, this method is expensive, particularly for crops where only specific organic matters need to be removed. Another practical conversion treatment technique for irrigation is chemical coagulation, which improves wastewater quality by reducing nitrogen levels. This is beneficial for soil conservation as well as protecting groundwater resources. The drawback of this method lies in its testing method, where it uses chemicals that could negatively impact soil and plants. Hence, the treated wastewater should be analyzed again before its application in irrigation to test whether it meets the standards for irrigation. Waste stabilization pond is the simplest and cheapest technique of all treatment methods, but it is not suggested for highly polluted wastewater. The batch reactor and Fenton process combine membrane and chemical treatments with the same pros and cons based on the added method. The negative impacts of wastewater irrigation, such as cost of the treatment process, consumption of materials and energy, emission to the atmosphere, disposal of filtered or sediment materials, etc., are also reviewed. Before applying treatment techniques in agricultural fields, serious attention should be paid. The adopted method may give rise to detrimental effects on health and the environment if not addressed properly.

\section{Funding}

This research received no external funding.

\section{Acknowledgments}

We would like to thank the National Institute of Biotechnology Malaysia and Universiti Putra Malaysia for the facilities provided to complete this study. The IPS Grant GPIPS/2016/9506500 through which this project has been funded and FRGS Grant 5540014 are greatly acknowledged.

\section{Conflicts of Interest}


The authors declare no conflict of interest.

\section{References}

1. Vigneswaran, S.; Sundaravadivel, M. In: Recycle and Reuse of Domestic Wastewater, in Wastewater Recycle, Reuse, and Reclamation. [Ed. Saravanamuthu (Vigi) Vigneswaran]. In: Encyclopedia of Life Support Systems (EOLSS). Developed under the Auspices of the UNESCO, Eolss Publishers, Oxford, UK, 2004.

2. The World Bank. Annual freshwater withdrawals, agriculture (\% of total freshwater withdrawal). Food and Agriculture Organization, AQUASTAT data, 2014.

3. Mcheik, M.; Toufaily, J.; Hassan, B.H.; Hamieh, T.; Abi Saab, M.T.; Rouphael, Y.; Ferracin, E.; da shio, B.; Bashabshah, I.; Al Hadidi, L. Reuse of treated municipal wastewater in irrigation: a case study from Lebanon and Jordan. Water and Environment Journal 2017, 31, 552-558, https://doi.org/10.1111/wej.12278.

4. Ungureanu, N.; Vlădut, V.; Voicu, G. Water Scarcity and Wastewater Reuse in Crop Irrigation. Sustainability 2020, 12, https://doi.org/10.3390/su12219055.

5. Khan, S.; Aijun, L.; Zhang, S.; Hu, Q.; Zhu, Y.Z. Accumulation of polycyclic aromatic hydrocarbons and heavy metals in lettuce grown in the soils contaminated with long-term wastewater irrigation. Journal of hazardous materials 2008, 152, https://doi.org/10.1016/j.jhazmat.2007.07.014.

6. Qin, Y.; Horvath A. Use of alternative water sources in irrigation: potential scales, costs, and environmental impacts in California. Environmental Research Communications 2020, 2, https://doi.org/10.1088/25157620/ab915e.

7. Chen, Z.; Ngo, H. H.; Guo, W. A critical review on sustainability assessment of recycled water schemes. Science of The Total Environment 2012, 426, 13-31, https://doi.org/10.1016/j.scitotenv.2012.03.055.

8. Parwin, R.; Paul, K.K. Assessment of kitchen wastewater quality for irrigation. Applied Water Science 2020, 10, https://doi.org/10.1007/s13201-020-01278-0.

9. Petrie, B.; Barden, R.; Kasprzyk-Hordern, B. A review on emerging contaminants in wastewaters and the environment: Current knowledge, understudied areas and recommendations for future monitoring. Water Research 2015, 72, 3-27, https://doi.org/10.1016/j.watres.2014.08.053.

10. Rahman, M.M.; Hagare, D.; Maheshwari, B. Use of Recycled Water for Irrigation of Open Spaces: Benefits and Risks. In: Balanced Urban Development: Options and Strategies for Liveable Cities 2016; pp. 261-288, https://doi.org/10.1007/978-3-319-28112-4_17.

11. Abourached, C.; English, M.J.; Liu, H. Wastewater treatment by Microbial Fuel Cell (MFC) prior irrigation water reuse. Journal of Cleaner Production, 2016, 137, 144-149, https://doi.org/10.1016/j.jclepro.2016.07.048.

12. Gukelberger, E.; Atiye, T.; Mamo, J.A.; Hoevenaars, K.; Galiano, F.; Figoli, A.; Gabriele, B.; Mancuso, R.; Nakyewa, P.; Akello, F.; Otim, R.; Mbilingi, B.; Adhiambo, S.C.; Lanta, D.; Musambyah, M.; Hoinkis, J. Membrane Bioreactor-Treated Domestic Wastewater for Sustainable Reuse in the Lake Victoria Region. Integrated Environmental Assessment and Management 2020, 16, 942-953, https://doi.org/10.1002/ieam.4281.

13. Mamat, N.H.; Ramli, S.; Abdullah, N.A.; Khan, S.; Gomes, C. Physical and soft sensor technologies for wastewater quality management. International Journal of Education and Management Engineering 2018, 8, 1-14, https://doi.org/10.5815/ijeme.2018.06.01.

14. Shanono, I.H.; Sapiee, M.R.M.; Aziz, K.A.; Suleiman, N.H.Z.; Gomes, A.; Gomes, C. Image Processing Techniques Applicable in Wastewater Quality Detection: Towards a Hygienic Environment. Journal of Materials and Environmental Sciences 2018, 9, 2288-2303.

15. Hu, Y.; Cheng, H.; Ji, J.; Li, Y-Y. A review of anaerobic membrane bioreactors for municipal wastewater treatment with a focus on multicomponent biogas and membrane fouling control. Environmental Science: Water Research and Technology 2020, 6, 2641-2663, https://doi.org/10.1039/D0EW00528B.

16. Catrinescu, C.; Chelba, A.; Teodosiu, C.; Apopei, P. Removal of diclofenac from secondary wastewater effluents by Fenton based processes. Environmental Engineering and Management Journal 2017, 16, 765777, https://doi.org/10.30638/eemj.2017.078.

17. Cheriyan, A.J.; Shaik, F.; Baawain, M.S.A.; Sarkar, J.P. A study on the removal of contaminants from secondary treated municipal wastewater by solar photocatalysis. Environmental Engineering and Management Journal 2017, 16, 1451-1456, https://doi.org/10.30638/eemj.2017.157.

18. Angelakis, A.N.; Asano, T.; Bahri, A.; Jimenez, B.E.; Tchobanoglous, G. Water Reuse: From Ancient to Modern Times and the Future. Frontiers in Environmental Science 2018, 6, 1-26, https://doi.org/10.3389/fenvs.2018.00026.

19. Asano, T.; Burton, F.L.; Leverenz, H.L.; Tsuchihashi, R.; Tchobanoglous, G. Water reuse: Issues, technologies, and applications. Eng. Sanit. Ambient 2007, 13, https://doi.org/10.1590/S141341522008000300001.

20. Abdullah, N.A.; Ramli, S.; Mamat, N.H.; Khan, S.; Gomes, C. Chemical and biosensor technologies for wastewater quality management. International Journal of Advanced Research and Publications 2017, 1, 110. 
21. Dahiru, A.R.; Nordin, N.B.; Ishak, M.N.; Mislan, M.S.B.; Gomes, C. Chemical method for wastewater management: Developments of Fenton process. International Journal of Advanced Research and Publications 2017, 1, 33-42.

22. Sandra, A.; Jamil, N.A.M.; Jabbar, S.; Sakyat, S.; Gomes, C. Aerobic and anaerobic sewage biodegradable processes: The gap analysis. International Journal of Research in Environmental Science 2017, 3, 9-19, https://doi.org/10.20431/2454-9444.0303002.

23. Ricart, S.; Rico, A.M.; Ribas, A. Risk-Yuck factor nexus in reclaimed wastewater for irrigation: comparing farmers' attitudes and public perception. Water 2019, 11, https://doi.org/10.3390/w11020187.

24. Becerra, C.; Lopes, A.; Vaz, I.; Silva, E.; Manaia, C.; Nunes, O. Wastewater reuse in irrigation: A microbiological perspective on implications in soil fertility and human and environmental health. Environment International 2015, 75, 117-135, https://doi.org/10.1016/j.envint.2014.11.001.

25. Matheyarasu, R.; Bolan, N.S.; Naidu, R. Abattoir Wastewater Irrigation Increases the Availability of Nutrients and Influences on Plant Growth and Development. Water Air Soil Pollut 2016, 227, https://doi.org/10.1007/s11270-016-2947-3.

26. Qadir, M.; Wichelns, D.; Raschid-Sally, L.; McCornick, P.G.; Drechsel, P.; Bahri, A.; Minhas, P.S. The challenges of wastewater irrigation in developing countries. Agricultural Water Management 2010, 97, 561568, https://doi.org/10.1016/j.agwat.2008.11.004.

27. Jaramillo, M.F.; Restrepo, I. Wastewater Reuse in Agriculture: A Review about Its Limitations and Benefits. Sustainability 2017, 9, 1-19, https://doi.org/10.3390/su9101734.

28. Livia, S.; María, M.S.; Marco, B.; Marco R. Assessment of wastewater reuse potential for irrigation in rural semiarid areas: the case study of Punitaqui, Chile. Clean Technologies and Environmental Policy 2020, 22, 1325-1338, https://doi.org/10.1007/s10098-020-01874-3.

29. Hashem, M.S.; Qi, X. Treated Wastewater Irrigation-A Review. Water 2021, 13, https://doi.org/10.3390/w13111527.

30. Goswami, R.; Shim, J.; Deka, S.; Kumari, D.; Kataki, R.; Kumar, M. Characterization of cadmium removal from aqueous solution by biochar produced from Ipomoea fistulosa at different pyrolytic temperatures. Ecological Engineering 2016, 97, 444-451, https://doi.org/10.1016/j.ecoleng.2016.10.007.

31. Guo, H.; Zhang, S.; Kou, Z.; Zhai, S.; Ma, W.; Yang, Y. Removal of cadmium (II) from aqueous solutions by chemically modified maize straw. Carbohydrate Polymers 2015, 115, 177-185, https://doi.org/10.1016/j.carbpol.2014.08.041.

32. Shakir, E.; Zahraw, Z.; Abdul Hameed, M.J.A. Environmental and health risks associated with reuse of wastewater for irrigation. Egyptian Journal of Petroleum 2017, 26, 95-102, https://doi.org/10.1016/j.ejpe.2016.01.003.

33. Du, J.; Park, K.; Yu, X.; Zhang, Y.J.; Ye, F. Massive pollutants released to Galveston Bay during Hurricane Harvey: Understanding their retention and pathway using Lagrangian numerical simulations. Science of The Total Environment 2020, 704, https://doi.org/10.1016/j.scitotenv.2019.135364.

34. Obasi, P.N.; Akudinobi, B.B. Potential health risk and levels of heavy metals in water resources of lead-zinc mining communities of Abakaliki, southeast Nigeria. Applied Water Science 2020, 10, https://doi.org/10.1007/s13201-020-01233-z.

35. Verlicchi, P.; Grillini, V. Surface water and groundwater quality in South Africa and Mozambique-Analysis of the most critical pollutants for drinking purposes and challenges in water treatment selection. Water 2020, 12, https://doi.org/10.3390/w12010305.

36. Edokpayi, J.N.; Odiyo, O.; Durowoju, O.S. Chapter 18-Impact of Wastewater on Surface Water Quality in Developing Countries: A Case Study of South Africa. In: Water Quality, edited by, H. Tutu, IntechOpen Publishers, Rijeka, 2017; https://doi.org/10.5772/66561.

37. Helmecke, M.; Fries, E.; Schulte, C. Regulating water reuse for agricultural irrigation: risks related to organic micro-contaminants. Environmental Sciences Europe 2020, 32, https://doi.org/10.1186/s12302-019-0283-0.

38. Visvanathan, C.; Ben Aim, R.; Parameshwaran, K. Membrane separation bioreactors for wastewater treatment. Critical Reviews in Environmental Science and Technology 2000, 30, 1-48, https://doi.org/10.1080/10643380091184165.

39. Al-Shammiri, M.; Al-Saffar, A.; Bohamad, S.; Ahmed, M. Wastewater quality and reuse in irrigation in Kuwait using microfiltration technology in treatment. Desalination 2005, 185, 213-225, https://doi.org/10.1016/j.desal.2005.02.078.

40. Khatri, P.; Gupta, K.K.; Gupta, R.K. Assessment of Water Quality Parameters in Real-Time Environment. SN Computer Science 2020, 1, https://doi.org/10.1007/s42979-020-00368-9.

41. Almedeij, J.; Al-Jarallah, R. Seasonal Variation Pattern of Monthly Wastewater Influent. Journal of Environmental Engineering 2011, 137, https://doi.org/10.1061/(ASCE)EE.1943-7870.0000332.

42. Radu, V.M.; Ivanov, A.A.; Ionescu, P.; Deák, G.; Tudor, M. Development of a multi-parametric quality index for water quality monitoring. Environmental Engineering and Management Journal 2016, 15, 1069-1074, https://doi.org/10.30638/eemj.2016.118.

43. Ezugbe, E.O.; Rathilal, S. Membrane Technologies in Wastewater Treatment: A Review. Membranes 2020, 10, https://doi.org/10.3390/membranes10050089. 
44. Iorhemen, O.T.; Hamza, R.A.; Tay, J.H. Membrane Bioreactor (MBR) Technology for Wastewater Treatment and Reclamation: Membrane Fouling. Membranes 2016, 6, https://doi.org/10.3390/membranes6020033.

45. Meng, F.; Chae, S.-R.; Drews, A.; Kraume, M.; Shin, H.-S.; Yang, F. Recent advances in membrane bioreactors (MBRs): Membrane fouling and membrane material. Water Research 2009, 43, 1489-1512, https://doi.org/10.1016/j.watres.2008.12.044.

46. Rosenberger, S.; Evenblij, H.; Te Poele, S.; Wintgens, T.; Laabs, C. The importance of liquid phase analyses to understand fouling in membrane assisted activated sludge processes-Six case studies of different European research groups. Journal of Membrane Science 2005, 263, 113-126, https://doi.org/10.1016/j.memsci.2005.04.010.

47. Munoz-Cupa, C.; Hu, Y.; Xu, C.; Bassi, A. An overview of microbial fuel cell usage in wastewater treatment, resource recovery and energy production. Science of The Total Environment 2021, 754, https://doi.org/10.1016/j.scitotenv.2020.142429.

48. World Health Organization (WHO). Health guidelines for the use of wastewater in agriculture and aquaculture: Report of a WHO scientific group [Meeting held in Geneva from 18 to 23 November 1987]. Geneva: World Health Organization, 1989.

49. Battilani, A.; Steiner, M.; Andersen, M.; Back, S. N.; Lorenzen, J.; Schweitzer, A.; Dalsgaard, A.; Forslund, A.; Gola, S.; Klopmann, W.; Plauborg, F.; Andersen, M.N. Decentralized water and wastewater treatment technologies to produce functional water for irrigation. Agricultural Water Management 2010, 98, 385-402, https://doi.org/10.1016/j.agwat.2010.10.010.

50. Semiat, R. Energy issues in desalination processes. Environmental science \& technology 2008, 42, 81938201, https://doi.org/10.1021/es801330u.

51. Park, K.; Kim, J.; Yang, D.R.; Hong, S. Towards a low-energy seawater reverse osmosis desalination plant: A review and theoretical analysis for future directions. Journal of Membrane Science 2020, 595, https://doi.org/10.1016/j.memsci.2019.117607.

52. Hoover, L.A.; Phillip, W.A.; Tiraferri, A.; Yip, N.Y.; Elimelech, M. Forward with osmosis: Emerging applications for greater sustainability. Environmental Science \& Technology 2011, 45, 9824-9830, https://doi.org/10.1021/es202576h.

53. Shaffer, D.L.; Yip, N.Y.; Gilron, J.; Elimelech, M. Seawater desalination for agriculture by integrated forward and reverse osmosis: Improved product water quality for potentially less energy. Journal of Membrane Science 2012, 415-416, 1-8, https://doi.org/10.1016/j.memsci.2012.05.016.

54. Davenport, D.M.; Deshmukh, A.; Werber, J.R.; Elimelech, M. High-Pressure Reverse Osmosis for EnergyEfficient Hypersaline Brine Desalination: Current Status, Design Considerations, and Research Needs. Environmental Science \& Technology Letters 2018, 5, 467-475, https://doi.org/10.1021/acs.estlett.8b00274.

55. Lin, S.H.; Chan, H.Y.; Leu, H.G. Treatment of wastewater effluent from an industrial park for agricultural irrigation. Desalination 2000, 128, 257-267, https://doi.org/10.1016/S0011-9164(00)00040-0.

56. Teh, C.Y.; Budiman, P.M.; Shak, K.P.Y.; Wu, T.Y. Recent Advancement of Coagulation-Flocculation and Its Application in Wastewater Treatment. Industrial \& Engineering Chemistry Research 2016, 55, 43634389, https://doi.org/10.1021/acs.iecr.5b04703.

57. Vigneswaran, S.; Ngo, H.H.; Chaudhary, D.S.; Hung, Y.T. Physicochemical treatment processes for water reuse. Physicochemical Treatment Processes 2005, 3, 635-676, https://doi.org/10.1385/1-59259-820-x:635.

58. Howe, K.J.; Hand, D.W.; Crittenden, J.C.; Trussell, R.R.; Tchobanoglous, G. Principles of Water Treatment. John Wiley \& Sons, 2012.

59. Ustun, G.E.; Solmaz, S.K.A.; Çiner, F.; Baskaya, H.S. Tertiary treatment of a secondary effluent by the coupling of coagulation-flocculation-disinfection for irrigation reuse. Desalination 2011, 277, 207-212, https://doi.org/10.1016/j.desal.2011.04.032.

60. Hung, Y.T.; Wang, L.K.; Shammas, N.K. Handbook of Environment and Waste Management: Air and Water Pollution Control. World Scientific Publishing Company, Illustrated edition (May 30, 2012), 2012.

61. Zaleschi, L.; Teodosiu, C.; Cretescu, I.; Rodrigo, M.A. A comparative study of electrocoagulation and chemical coagulation processes applied for wastewater treatment. Environmental Engineering and Management Journal 2012, 11, 1517-1525, https://doi.org/10.30638/eemj.2012.190.

62. Omar, I. Evaluation of Water Quality and the Efficiency of Ifraz-2 Water treatment plant-Units. Journal of University of Raparin 2019, 6, 121-138, https://doi.org/10.26750/Vol(6).no(2).paper9.

63. Wang, W.; Xu, Z.; Li, H.; Jin, W. Coagulation characteristics of organic pollutants removal in CSO wastewater treatment. Environmental Engineering and Management Journal 2016, 15, 75-80, https://doi.org/10.30638/eemj.2016.009.

64. Saleem, M.; Alaadin, A.; Bukhari, M.; Akram, N. Electrocoagulation for the treatment of wastewater for reuse in irrigation and plantation. Journal of Basic and Applied Sciences, 2011, 7, 11-20.

65. Secula, M.S.; Crețescu, I.; Petrescu, S. Electrocoagulation treatment of sulfide wastewater in a batch reactor: Effect of electrode material on electrical operating costs. Environmental Engineering and Management Journal 2012, 11, 1485-1491, https://doi.org/10.30638/eemj.2012.186.

66. Jing, G.; Ren, S.; Gao, Y.; Sun, W.; Gao, Z. Electrocoagulation: A Promising Method to Treat and Reuse Mineral Processing Wastewater with High COD. Water 2020, 12, https://doi.org/10.3390/w12020595. 
67. Zaied, B.K.; Rashid, M.; Nasrullah, M.; Zularisam, A.W.; Pant, D.; Singh, L. A comprehensive review on contaminants removal from pharmaceutical wastewater by electrocoagulation process. Science of The Total Environment 2020, 726, https://doi.org/10.1016/j.scitotenv.2020.138095.

68. Qasem, N.A.A.; Mohammed, R.H.; Lawal, D.U. Removal of heavy metal ions from wastewater: a comprehensive and critical review. npj Clean Water 2021, 4, https://doi.org/10.1038/s41545-021-00127-0.

69. Riera-Torres, M.; Gutiérrez-Bouzán, C.; Crespi, M. Combination of coagulation-flocculation and nanofiltration techniques for dye removal and water reuse in textile effluents. Desalination 2010, 252, 53-59, https://doi.org/10.1016/j.desal.2009.11.002.

70. Ebeling, M.; Sibrell, P.L.; Ogden, S.R.; Summerfelt, S.T. Evaluation of chemical coagulation-flocculation aids for the removal of suspended solids and phosphorus from intensive recirculating aquaculture effluent discharge. Aquacultural Engineering 2003, 29, 23-42, https://doi.org/10.1016/S0144-8609(03)00029-3.

71. Iloms, E.; Ololade, O.O.; Ogola, H.J.O.; Selvarajan, R. Investigating Industrial Effluent Impact on Municipal Wastewater Treatment Plant in Vaal, South Africa. Int. J. Environ. Res. Public Health 2020, 17, https://doi.org/10.3390/ijerph17031096.

72. Atashzaban, Z.; Seidmohammadi, A.; Nematollahi, D.; Azarian, G.; Shayesteh, O.H.; Rahman, A.R. The Efficiency of Electrocoagulation and Electroflotation Processes for Removal of Polyvinyl Acetate from Synthetic Effluent. Avicenna J Environ Health Eng. 2016, 3, https://doi.org/10.5812/ajehe.7469.

73. Gabarró, J.; Batchellí, L.; Balaguer, M.D.; Puig, S.; Colprim, J. Grey water treatment at a sports centre for reuse in irrigation: A case study. Environmental Technology 2012, 34, https://doi.org/10.1080/09593330.2012.750382.

74. Ghazani, M.T.; Taghdisian, A. Performance evaluation of a hybrid sequencing batch reactor under saline and hyper saline conditions. Journal of Biological Engineering 2019, 13, https://doi.org/10.1186/s13036-0190192-1.

75. Lin, S.H.; Cheng, K.W. A new sequencing batch reactor for treatment of municipal sewage wastewater for agricultural reuse. Desalination 2001, 133, 41-51, https://doi.org/10.1016/S0011-9164(01)00081-9.

76. Hodaifa, G.; Ochando-Pulido, J.M.; Rodriguez-Vives, S.; Martinez-Ferez, A. Optimization of continuous reactor at pilot scale for olive-oil mill wastewater treatment by Fenton-like process. Chemical Engineering Journal 2013, 220, 117-124, https://doi.org/10.1016/j.cej.2013.01.065.

77. Victor-Ortega, M.D.; Ochando-Pulido, J.M.; Martínez-Ferez, A. Iron removal and reuse from Fenton-like pretreated olive mill wastewater with novel strong-acid cation exchange resin fixed-bed column. Journal of Industrial and Engineering Chemistry 2016, 36, 298-305, https://doi.org/10.1016/j.jiec.2016.02.019.

78. Nieto, L.M.; Hodaifa, G.; Rodríguez, S.; Giménez, J. A.; Ochando, J. Degradation of organic matter in oliveoil mill wastewater through homogeneous Fenton-like reaction. Chemical Engineering Journal 2011, 173, 503-510, https://doi.org/10.1016/j.cej.2011.08.022.

79. Abou-Shady, A. Effect of separated cathode on the removal of dissolved organic carbon using anode oxidation, Fenton oxidation, and coagulation. Journal of Environmental Chemical Engineering 2016, 4, 704710, https://doi.org/10.1016/j.jece.2015.12.021.

80. Esteban García, A.B.; Szymański, K.; Mozia, S.; Perez, J.A.S. Treatment of laundry wastewater by solar photo-Fenton process at pilot plant scale. Environmental Science and Pollution Research 2021, 28, 85768584, https://doi.org/10.1007/s11356-020-11151-X.

81. Verbyla, M.E.; Mihelcic, J.R. A review of virus removal in wastewater treatment pond systems. Water Research 2015, 71, 107-124, https://doi.org/10.1016/j.watres.2014.12.031.

82. Polprasert, C.; Kittipongvises, S. Constructed Wetlands and Waste Stabilisation Ponds. Treatise on Water Science 2011, 4, 277-299, https://doi.org/10.1016/B978-0-444-53199-5.00090-7.

83. Mansouri, B.; Ebrahimpour, M. Heavy metals characteristics of wastewater stabilisation ponds. Agriculture and Environmental Science 2011, 10, 763-768.

84. Mcnaughton, E.; Stoll, S. J.; Smith Jr., J.E.; Middlebrooks, E.J.; Bowman, R.H. Principles of Design and Operations of Wastewater Treatment Pond Systems for Plant Operators, Engineers, and Managers. In: U.S. Environmental Protection Agency Report, Washington DC, USA, EPA/600/R-11/088, 2011.

85. Noyola, A.; Padilla-Rivera, A.; Morgan-Sagastume, J.M.; Güereca, L.P.; Hernández-Padilla, F. Typology of Municipal Wastewater Treatment Technologies in Latin America. Clean Soil Air Water 2012, 40, 926-932, https://doi.org/10.1002/clen.201100707.

86. Kouraa, A.; Fethi, F.; Fahde, A.; Lahlou, A.; Ouazzani, N. Reuse of urban wastewater treated by a combined stabilisation pond system in Benslimane (Morocco). Urban Water 2002, 4, 373-378, https://doi.org/10.1016/S1462-0758(01)00067-X.

87. Gopolang, O.P.; Letshwenyo, M.W. Performance Evaluation of Waste Stabilisation Ponds. Journal of Water Resource and Protection 2018, 10, https://doi.org/10.4236/jwarp.2018.1011067.

88. Kumar, R.; Kumar, P. Wastewater Stabilisation Ponds: Removal of Emerging Contaminants. Journal of Sustainable Development of Energy, Water and Environment Systems 2020, 8, 344-359, https://doi.org/10.13044/j.sdewes.d7.0291.

89. Verbyla, M.E.; Iriarte, M.M.; Guzmán, A.M.; Coronado, O.; Almanza, M.; Mihelcic, J.R. Pathogens and faecal indicators in waste stabilisation pond systems with direct reuse for irrigation: Fate and transport in 
water, soil and crops. Science of The Total Environment 2016, 551-552, 429-437, https://doi.org/10.1016/j.scitotenv.2016.01.159.

90. Madera, C.A.; Peña, M.R.; Mara, D.D. Microbiological quality of a waste stabilisation pond effluent used for restricted irrigation in Valle Del Cauca, Colombia. Water Science and Technology 2002, 45, 139-143, https://doi.org/10.2166/wst.2002.0019.

91. Oakley, S.M.; Mendonça, L.C.; Mendonça, S.R. Sludge removal from primary wastewater stabilization ponds with excessive accumulation: a sustainable method for developing regions. Journal of Water, Sanitation and Hygiene for Development 2012, 2, 68-78, https://doi.org/10.2166/washdev.2012.093.

92. Edokpayi, J.N.; Odiyo, J.O.; Popoola, O.E.; Msagati, T.A.M. Evaluation of contaminants removal by waste stabilization ponds: A case study of Siloam WSPs in Vhembe District, South Africa. Heliyon 2021, 7 , https://doi.org/10.1016/j.heliyon.2021.e06207.

93. dos Santos, S.L.; van Haandel, A. Transformation of Waste Stabilization Ponds: Reengineering of an Obsolete Sewage Treatment System. Water 2021, 13, https://doi.org/10.3390/w13091193.

94. Wei, F.; Zhang, H.; Ren, Q.; Chen, H.; Yang, L.; Ding, B.; Yu, M.; Liang, Z. Removal of organic contaminants from wastewater with GO/MOFs composites. Plos One 2021, 16, https://doi.org/10.1371/journal.pone.0253500.

95. El-Sheekh, M.; El-Dalatony, M.M.; Thakur, N.; Zheng, Y.; El-Sayed, S. Role of microalgae and cyanobacteria in wastewater treatment: genetic engineering and omics approaches. International Journal of Environmental Science and Technology 2021, https://doi.org/10.1007/s13762-021-03270-w.

96. Abdel-Raouf, N.; Al-Homaidan, A.A.; Ibraheem, I.B. Microalgae and wastewater treatment. Saudi Journal of Biological Sciences 2012, 19, 257-275, https://doi.org/10.1016/j.sjbs.2012.04.005.

97. Gallego-Valero, L.; Moral-Parajes, E.; Román-Sánchez, I.M. Wastewater treatment costs: A research overview through bibliometric analysis. Sustainability 2021, 13, https://doi.org/10.3390/su13095066.

98. Huang, Y.; Zhao, Z.; Xu, M.; Gao, Y. Biological approaches for disposing and reusing chemical wastewater. Ecological Engineering 2000, 16, 281-292, https://doi.org/10.1016/S0925-8574(00)00105-1.

99. Mara, D.D.; Pearson, H.W. A hybrid waste stabilisation pond and wastewater storage and treatment reservoir system for wastewater reuse for both restricted and unrestricted crop irrigation. Water Research 1999, 33, 591-594, https://doi.org/10.1016/S0043-1354(98)00238-3.

100.Khan, M.A.; Shaukat, S.S.; Khan, M.A. Economic benefits from irrigation of maize with treated effluent of waste stabilisation ponds. Pakistan Journal of Botany 2008, 40, 1091-1098.

101.Melián, J.A.H.; Araña, J.; González Díaz, O.; Aguiar Bujalance, M.E.; Doña Rodríguez, J.M. Effect of stone filters in a pond-wetland system treating raw wastewater from a university campus. Desalination 2009, 237, 277-284, https://doi.org/10.1016/j.desal.2008.01.021.

102.Ungureanu, N.; Vlăduț, V.; Voicu, G. Water Scarcity and Wastewater Reuse in Crop Irrigation. Sustainability 2020, 12, https://doi.org/10.3390/su12219055.

103.Elgallal, M.; Fletcher, L.; Evans, B. Assessment of potential risks associated with chemicals in wastewater used for irrigation in arid and semiarid zones: A review. Agricultural Water Management 2016, 177, 419431, https://doi.org/10.1016/j.agwat.2016.08.027.

104. Srinivasan, J.T.; Reddy, V.R. Impact of irrigation water quality on human health: A case study in India. Ecological Economics 2009, 68, 2800-2807, https://doi.org/10.1016/j.ecolecon.2009.04.019.

105. WHO Guidelines for the safe use of wastewater, excreta and greywater. 1: Policy and regulatory aspects, France 2006.

106.Abaidoo, R.C.; Keraita, B.; Drechsel, P.; Dissanayake, P.; Maxwell, A.S. Soil and Crop Contamination Through Wastewater Irrigation and Options for Risk Reduction in Developing Countries. Soil Biology and Agriculture in the Tropics, Soil Biology Book Series, Springer, Berlin, Heidelberg 2010, 21, 275-297, https://doi.org/10.1007/978-3-642-05076-3_13.

107.GB 15618-2018, Environmental quality standard for soils. National Standard of the People's Republic of China 2018.

108. Chen, S-B.; Wang, M.; Li, S-S.; Zhao, Z-Q.; E, W-D. Overview on current criteria for heavy metals and its hint for the revision of soil environmental quality standards in China. Journal of Integrative Agriculture 2018, 17, 765-774, https://doi.org/10.1016/S2095-3119(17)61892-6.

109. Yan, A.; Wang, Y.; Tan, S.N.; Yusof, M.L.M.; Ghosh, S.; Chen, Z. Phytoremediation: A Promising Approach for Revegetation of Heavy Metal-Polluted Land. Frontiers in Plant Science 2020, 11, https://doi.org/10.3389/fpls.2020.00359.

110.Khan, M.U.; Malik, R.N.; Muhammad, S. Human health risk from Heavy metal via food crops consumption with wastewater irrigation practices in Pakistan. Chemosphere 2013, 93, 2230-2238, https://doi.org/10.1016/j.chemosphere.2013.07.067.

111.Agoro, M.A.; Adeniji, A.O.; Adefisoye, M.A.; Okoh, O.O. Heavy Metals in Wastewater and Sewage Sludge from Selected Municipal Treatment Plants in Eastern Cape Province, South Africa. Water 2020, 12, 2746, https://doi.org/10.3390/w12102746.

112.Preisner, M.; Neverova-Dziopak, E; Kowalewski, Z. Mitigation of eutrophication caused by wastewater discharge: A simulation-based approach. Ambio 2021, 50, 413-424, https://doi.org/10.1007/s13280-02001346-4. 
113.Qadir, M.; Scott, C.A. Non-pathogenic trade-offs of wastewater irrigation. In: Wastewater irrigation and health: Assessing and mitigating risk in low income countries. Drechsel, P.; Scott, C.A.; Raschid-Sally, L.; Redwood, M; Bahri, A. (eds.), London: Earthscan, UK. 2010.

114.Nagabalaji, V.; Sivasankari, G.; Srinivasan, S.V.; Suthanthararajan, R.; Ravindranath, E. Nutrient removal from synthetic and secondary treated sewage and tannery wastewater through phycoremediation. Environmental Technology 2019, 40, 784-792, https://doi.org/10.1080/09593330.2017.1408689.

115.Obayomi, O.; Edelstein, M.; Safi, J.; Mihiret, M.; Ghazaryan, L.; Vonshak, A.; Bernstein, N.; Gillor, O. The combined effects of treated wastewater irrigation and plastic mulch cover on soil and crop microbial communities. Biol Fertil Soils 2020, 56, 729-742, https://doi.org/10.1007/s00374-020-01442-3.

116.Fattal, S.; Shuval, H.; Wax, Y.; Davies, A. Study of enteric disease transmission associated with wastewater utilization in agricultural communities in Israel. Proceedings of the Water Rescue Symposium II 1991, 3.

117.Simmons, R.; Qadir, M.; Drechsel, P. Farm-based measures for reducing human and environmental health risks from chemical constituents in wastewater. In: Wastewater Irrigation and Health: Assessing and Mitigating Risk in Low-income Countries. Rechsel, P.; Scott, C.A.; Raschid-Sally, L.; Redwood, M.; Bahri, A. (Eds.). Erthscan, London, 2010.

118. Anna, O.; Melania, M.; Katarzyna, D-S.; Andrea, M.; Katarzyna, S.-Ś; Rosario, N.; Aneta, B.; Loredana, C.; Flavia, P. When Salt Meddles Between Plant, Soil, and Microorganisms. Frontiers in Plant Science 2020, 11, https://doi.org/10.3389/fpls.2020.553087.

119.Touil, S.; Chabaca, M.N.; Hasbaia, O. Impact assessment of long treated wastewater irrigation on soil and crops in Algeria. Euro-Mediterranean Journal for Environmental Integration 2020, 5, https://doi.org/10.1007/s41207-020-00187-7.

120. Manciulea, I.; Bogatu, C.; Dumitrescu, L.; Draghici, C. $\mathrm{Cu}^{2+}$ removal from wastewaters by using compost as sorbent. Environmental Engineering and Management Journal 2017, 16, 779-792.

121.Tofan, L.; Wenkert, R.; Paduraru, C. Natural and waste materials as green sorbents for Cd (II) removal from aqueous effluents. Environmental Engineering and Management Journal 2016, 15, 1049-1058, https://doi.org/10.30638/eemj.2016.116.

122.Piña, B.; Bayona, J.M.; Christou, A.; Fatta-Kassinos, D.; Guillon, E.; Lambropoulou, D.; Michael, C.; Polesel, F.; Sayen, S. On the contribution of reclaimed wastewater irrigation to the potential exposure of humans to antibiotics, antibiotic resistant bacteria and antibiotic resistance genes-NEREUS COST Action ES1403 position paper. Journal of Environmental Chemical Engineering 2018, 8, https://doi.org/10.1016/j.jece.2018.01.011.

123.Rizzo, L.; Manaia, C.; Merlin, C.; Schwartz, T.; Dagot, C.; Ploy, M.C.; Michael, I.; Fatta-Kassinos, D. Urban wastewater treatment plants as hotspots for antibiotic resistant bacteria and genes spread into the environment: a review. Science of The Total Environment 2013, 447, 345-360, https://doi.org/10.1016/j.scitotenv.2013.01.032.

124.Hassan, M.; Zhu, G.; LU, Y.; AL-Falahi, A.H.; Yuan L.U.; Huang, S.; Wan, Z. Removal of antibiotics from wastewater and its problematic effects on microbial communities by bioelectrochemical Technology: Current knowledge and future perspectives. Environmental Engineering Research 2021, 26, https://doi.org/10.4491/eer.2019.405.

125.Sabri, N.A.; Schmitt, H.; Van der Zaan, B.; Gerritsen, H.W.; Zuidema, T.; Rijnaarts, H.H.M.; Langenhoff, A.A.M. Prevalence of antibiotics and antibiotic resistance genes in a wastewater effluent-receiving river in the Netherlands. Journal of Environmental Chemical Engineering 2020, 8, https://doi.org/10.1016/j.jece.2018.03.004.

126.Stec, M.; Jagustyn, B.; Słowik, K.; Ściążko, M.; Iluk, T. Influence of High Chloride Concentration on pH Control in Hydroxide Precipitation of Heavy Metals. Journal of Sustainable Metallurgy 2020, 6, 239-249, https://doi.org/10.1007/s40831-020-00270-x.

127. Abegunrin, T.P.; Awe, G.O.; Olufemi, I.; Modupe, A. Impact of wastewater irrigation on soil physic-chemical properties, growth and water use pattern of two indigenous vegetables in SouthWest Nigeria. Catena 2016, 139, 167-178, https://doi.org/10.1016/j.catena.2015.12.014.

128. Tabatabael, S.H.; Najafi, P. Effects of irrigation with treated municipal wastewater on soil properties in arid and semiarid regions. Journal of Irrigation and Drainage 2009, 58, 551-560, https://doi.org/10.1002/ird.449.

129.Preisner, M.; Neverova-Dziopak, E.; Kowalewski, Z. An Analytical Review of Different Approaches to Wastewater Discharge Standards with Particular Emphasis on Nutrients. Environmental Management 2020, 66, 694-708, https://doi.org/10.1007/s00267-020-01344-y.

130.Tatjana, S.; Vrishali, S.; Ganapathy, G.; David, T.; Rohini, P. Wastewater Discharge Standards in the Evolving Context of Urban Sustainability-The Case of India. Frontiers in Environmental Science 2020, 8, 130, https://doi.org/10.3389/fenvs.2020.00030.

131. Sheikh, B.; Nelson, K.L.; Haddad, B.; Thebo, A. Grey water: Agricultural use of reclaimed water in California. Journal of Contemporary Water Research \& Education 2018, 165, 28-41, https://doi.org/10.1111/j.1936-704X.2018.03291.x.

132.Deng, S.; Yan, X.; Zhu, Q.; Liao, C. The utilization of reclaimed water: Possible risks arising from waterborne contaminants. Environmental Pollution 2019, 254, https://doi.org/10.1016/j.envpol.2019.113020. 
133. Schmidt, C.W. The yuck factor: when disgust meets discovery. Environmental health perspectives 2008, 116, A524-A527, https://doi.org/10.1289/ehp.116-a524.

134. Ricart, S.; Rico, A.M. Assessing technical and social driving factors of water reuse in agriculture: A review on risks, regulation and the yuck factor. Agricultural Water Management 2019, 217, 426-439, https://doi.org/10.1016/j.agwat.2019.03.017.

135.Sarah, G.H.; Thaura, G-H. Heavy metals in soils and the remediation potential of bacteria associated with the plant microbiome. Frontiers in Environmental Science 2021, 9, 1-15, https://doi.org/10.3389/fenvs.2021.604216.

136.Praus, P. Principal Component Weighted Index for Wastewater Quality Monitoring. Water 2019, 11, https://doi.org/10.3390/w11112376. 